(๔) 2018 - ISSN 1807-2577

\title{
Effect of tooth enamel staining by coffee consumption during at-home tooth bleaching with carbamide peroxide
}

\author{
Efeito da coloração do esmalte dentário pelo consumo de café durante o \\ clareamento dentário caseiro com peróxido de carbamida
}

\author{
João Victor Frazão CÂMARA ${ }^{a *}$ (D), Luine de Paiva Pereira Santos de SOUZA ${ }^{\mathrm{b}}$ (D), \\ Daniel Otero Amaral VARGAS ${ }^{b}$ (1), Isabel Ferreira BARBOSA ${ }^{c}$ (1), \\ Gisele Damiana da Silveira PEREIRA ${ }^{\mathrm{b}}$ (])
}

aUSP - Universidade de São Paulo, Faculdade de Odontologia de Bauru, Departamento de Ciências Biológicas, Bauru, SP, Brasil

bUFRJ - Universidade Federal do Rio de Janeiro, Faculdade de Odontologia, Departamento de Clínica Odontológica, Rio de Janeiro, RJ, Brasil

'UNICAMP - Universidade Estadual de Campinas, Faculdade de Odontologia de Piracicaba, Departamento de Odontologia Restauradora, Piracicaba, SP, Brasil

\begin{abstract}
How to cite: Câmara JVF, Souza LPPS, Vargas DOA, Barbosa IF, Pereira GDS. Effect of tooth enamel staining by coffee consumption during at-home tooth bleaching with carbamide peroxide. Rev Odontol UNESP. 2020;49:e20200024. https://doi.org/10.1590/1807-2577.02420
\end{abstract}

\begin{abstract}
Resumo
Introdução: A obtenção do resultado esperado durante o clareamento dental exige um diagnóstico correto do tipo de coloração apresentado. As causas da coloração dos dentes diferem dependendo do fator etiológico. Objetivo: Avaliar a mudança de cor causada pela imersão dos dentes bovinos na solução de café durante o clareamento dentário caseiro, utilizando gel de peróxido de carbamida a 16\%. Material e método: Trinta e três dentes bovinos hígidos foram distribuídos em três grupos de onze dentes cada: 1 - Dentes clareados quatro horas por dia durante 21 dias; 2 - Dentes clareados quatro horas por dia durante 21 dias e imerso em solução de café imediatamente após o clareamento dentário; 3 - Dentes clareados quatro horas por dia durante 21 dias e imerso em solução de café quatro horas após o término do clareamento dentário. Imersão em café foi realizada durante 15 minutos e a cor dos dentes foi avaliada antes do início do procedimento do clareamento e após 21 dias com um espectrofotômetro intraoral. 0 teste Shapiro-Wilk foi utilizado para avaliar a homocedasticidade e os dados foram submetidos à análise de variância de um fator (ANOVA) e ao teste de Tukey $(\mathrm{p}<0,05)$. Resultado: A mudança de cor observada no grupo $1(5,76 \pm 2,74)^{A}$ não foi estatisticamente diferente do grupo $2(8,83 \pm 5,11)^{A}$, imerso em solução de café imediatamente após o clareamento dentário, e do grupo 3, imerso em café quatro horas após o clareamento dental $(8,20 \pm 3,71)$. Conclusão: 0 café não interferiu nos resultados do clareamento dental, independentemente do tempo após o procedimento. Portanto, restrições alimentares não são necessárias durante o clareamento dental.
\end{abstract}

Descritores: Clareamento dentário; estética; agentes corantes; café.

\begin{abstract}
Introduction: Obtaining the result expected during tooth bleaching requires a correct diagnosis of the type of staining presented. The causes of tooth staining differ depending on the etiological factor. Objective: To assess the color change caused by the immersion of bovine teeth in coffee solution during at-home tooth bleaching using a 16\% carbamide peroxide gel. Material and method: Thirtythree sound bovine teeth were assigned to three groups of eleven teeth each: 1 - Teeth bleached (TB) four hours per day for 21 days; 2 - TB four hours per day for 21 days and immersed in coffee solution immediately after tooth bleaching; 3 - TB four hours per day for 21 days and immersed in coffee solution four hours after the end of tooth bleaching. Immersed in coffee was performed for 15 minutes
\end{abstract}


and tooth color was assessed before the start of the bleaching procedure and after 21 days with an intraoral spectrophotometer. Test Shapiro-Wilk was used to assess homoscedasticity and data were submitted to one-factor Analysis of Variance (ANOVA) and Tukey's test $(\mathrm{p}<0.05)$. Result: The color change observed in group $1(5.76 \pm 2.74)^{\mathrm{A}}$ was not statistically different from group $2(8.83 \pm 5.11)^{\mathrm{A}}$, which was immersed in coffee solution immediately after tooth bleaching, and from group 3 , which was immersed in coffee solution four hours after tooth bleaching $(8.20 \pm 3.71)^{\mathrm{A}}$. Conclusion: Coffee did not interfere with the tooth bleaching results, regardless of the time after the procedure. Hence, diet restrictions are not necessary during tooth bleaching.

Descriptors: Tooth bleaching; aesthetics; coloring agents; coffee.

\section{INTRODUCTION}

Smile aesthetics is an essential part of the conception of health and well-being of the population. Among aesthetic treatments, tooth bleaching is considered a conservative and effective treatment, thus attaining the beauty pattern demands promoted in modern society ${ }^{1,2}$.

Obtaining the result expected during tooth bleaching requires a correct diagnosis of the type of staining presented. The causes of tooth staining differ depending on the etiological factor, and they are classified in two main groups: intrinsic and extrinsic staining ${ }^{3-5}$. The most common and effective techniques for tooth bleaching are at-home, in-office, or the association of both, and they depend on the needs of each patient and the level of staining observed 4 . Inoffice tooth bleaching uses bleaching gels at high concentrations of carbamide peroxide, while at-home tooth bleaching usually applies carbamide peroxide daily and at lower concentrations. At-home tooth bleaching is effective and extensively promoted due to the reduced time in dental visits, lower cost to patients, and lower risk of tooth sensitivity after the procedure 6 .

The professional recommendations during tooth bleaching determine that patients should avoid smoking and stop consuming foods rich in coloring agents such as soft drinks, wine, teas, and coffee, thus embracing a white diet $^{6}$. Some studies show that changes such as loss of organic material on the surface of tooth enamel after bleaching result in amore porous surface full of irregularities, which becomes more susceptible to extrinsic pigmentation ${ }^{6-8}$.

Moreover, the consumption of foods rich in coloring agents such as coffee, tea, or colabased soft drinks in these conditions may change even more the structure of the bleached ename $^{7,9}$ so it becomes more prone to staining immediately after the bleaching procedure ${ }^{5,10}$. Hence, some substances from the diet may compromise an efficient and lasting result of the tooth bleaching performed, causing staining both during and after the treatment ${ }^{8}$.

Although some authors concluded that coffee consumption affects negatively the bleaching treatment, others show no clinical evidence of staining by coffee after tooth bleaching $6,7,11$. Farawati et al. ${ }^{12}$ observed through SEM assessment that tooth bleaching with carbamide peroxide does not change the topography of enamel surface and therefore it does not increase the susceptibility to staining, regardless of the concentration used.

Thus, this study aimed to determine the effect of tooth enamel staining by coffee consumption during at-home tooth bleaching with $16 \%$ carbamide peroxide using the quantified parameters of the CIE Lab system in the following treatments: 1) Teeth stained with coffee solution daily, immediately after tooth bleaching; and 2) Teeth stained with coffee solution daily, four hours after the end of tooth bleaching. The following null hypotheses were tested: coffee ingestion does not interfere with the color change at the end of tooth whitening, immediately and 4 hours after the end of the procedure. 


\section{MATERIAL AND METHOD}

\section{Sample Preparations}

Thirty-three sound bovine teeth were used in this study and were stored for one month in an $8 \%$ thymol solution after their extractions. For specimen preparations, the surfaces of tooth enamel were polished respectively with \#400, \#600, and \#1200-grit silicon carbide papers (Carborundum/3M do Brasil Ltda., Sumaré, SP, Brazil) ${ }^{2}$ manually, with standard time of 30 seconds, and paying attention so the surface would be regulated similarly in its entire extension. For the first part of the study, an addition silicone mold was produced (Variotime HeraeusKulzer, Hanau, Germany) in the buccal aspect of one single specimen to standardize the positioning during the spectrophotometer reading.

A bleaching agent (Whiteness Perfect 16\%, FGM, Joinville, SC, Brazil), instant coffee (Nescafé Tradição, Nestlé, Araras, SP, Brazil), and artificial saliva (Compounding pharmacy of the Federal University of Rio de Janeiro, Rio de Janeiro, RJ, Brazil) were used (Table 1).

Table 1. Commercial brand, composition, and manufacturers of the materials used in the analysis of tooth enamel staining by coffee consumption during at-home tooth bleaching with $16 \%$ carbamide peroxide

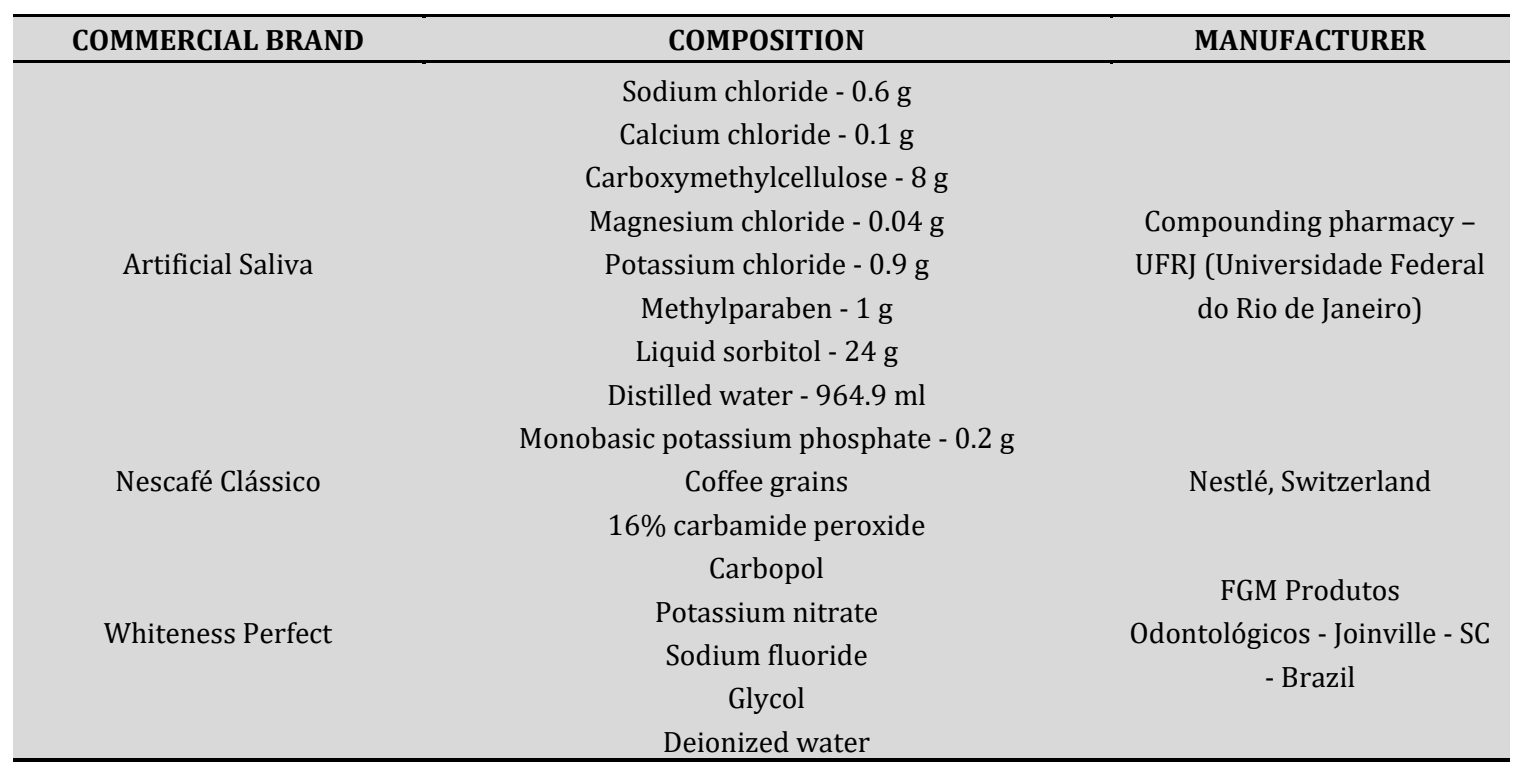

\section{Experimental Groups}

- Group 1 - At-home tooth bleaching with 16\% carbamide peroxide, daily for four hours, for three consecutive weeks, and later storage in artificial saliva (positive control group);

- Group 2 - At-home tooth bleaching with $16 \%$ carbamide peroxide, daily for four hours for three consecutive weeks, and daily coffee immersion for 15 minutes immediately after the end of tooth bleaching. After these procedures, the teeth were stored in artificial saliva for the time remaining;

- Group 3 - At-home tooth bleaching with 16\% carbamide peroxide, daily for four hours for three consecutive weeks, and daily coffee immersion for 15 minutes four hours after the end of tooth bleaching. After these procedures, the teeth were stored in artificial saliva for the time remaining. 


\section{Study Design}

\section{Tooth Bleaching}

The 16\% carbamide peroxide Whiteness Perfect bleaching gel was used for at-home tooth bleaching. The carbamide peroxide gel was manipulated according to the manufacturer's recommendations, which consist of applying the gel directly on the buccal surfaces of tooth enamel. The teeth were immersed partially in artificial saliva, leaving the buccal surfaces of enamel exposed, to which the Whiteness Perfect bleaching gel was applied directly, filling the entire area.

Tooth bleaching was performed in vitro daily for four hours, according to the manufacturer's instructions, for three consecutive weeks. The gel was removed with a careful wash in running water and then the teeth were stored again in artificial saliva at room temperature, which was replaced daily to maintain its properties.

\section{Pigmentation Protocol}

The samples from groups 2 and 3 were pigmented with coffee (Nescafé Classic, Nestle, Switzerland $)^{5}$ using one teaspoon of coffee for the mixture, which exact quantity was obtained with a specific marked recipient. Next, $0,9 \mathrm{~g}$ of soluble coffee was dissolved in $50 \mathrm{ml}$ of boiling water, as suggested by the manufacture ${ }^{11}$. Staining was performed by immersing the specimens in coffee for 15 minutes ${ }^{10}$ once a day, and then the samples were washed in running water and stored again in artificial saliva until the next bleaching and staining sessions.

\section{Color Analysis}

Color analyses were performed in enamel at the two following times: Before the start of tooth bleaching ( $\mathrm{t} 0$ ), with the teeth stored in artificial saliva for 24 hours, and after three weeks, at the end of tooth bleaching (tf) ${ }^{5}$. For color readings, the bovine teeth were placed in the addition silicone mold for standardization. A Vita Easyshade ${ }^{\mathrm{TM}}$ Advance 4.0 spectrophotometer (VITA Zahnfabrik H. RauterGmbH \& Co, BadSäckingen, Germany) was used, which was previously calibrated according to the manufacturer's recommendations.

Color was determined using the quantified parameters of the CIE Lab system with three coordinates: $\mathrm{L}^{*},\left(\mathrm{a}^{*}\right)$ and $\left(\mathrm{b}^{*}\right)$. The $\mathrm{L}^{*}$ describes the tooth value in a scale from 0 (black) to 100 (white); $\left(\mathrm{a}^{*}\right)$ is the measure along the red-green axis, with positive $\left(\mathrm{a}^{*}\right)$ indicating the red color and negative $\left(\mathrm{a}^{*}\right)$ indicating the green color; and $\left(\mathrm{b}^{*}\right)$ is the measure along the blue-yellow axis, with positive $\left(\mathrm{b}^{*}\right)$ indicating the yellow color and negative $\left(\mathrm{b}^{*}\right)$ indicating the blue color. The color comparison before and after the treatment is determined by the difference between both color measurements $(\Delta \mathrm{E})$, and it was calculated using the formula $\Delta \mathrm{E}=\left[\left(\Delta \mathrm{L}^{*}\right)^{2}+\left(\Delta \mathrm{a}^{*}\right)^{2}\right.$ $\left.+\left(\Delta \mathrm{b}^{*}\right)^{2}\right]^{1 / 2}$. When $\Delta \mathrm{E}$ is higher than 3.7 , an easily visible difference is considered, when it is between 3.7 and 1 , a clinically acceptable difference is considered, and when $\Delta \mathrm{E}$ is lower than 1 , a clinically non-perceptible difference is considered ${ }^{2}$.

\section{Statistical Analysis}

The values obtained in the readings before and after pigmentation were subjected to analysis of data normality using the Shapiro-Wilk and Levene tests to assess homoscedasticity. The data obtained were subjected to one-factor Analysis of Variance (ANOVA) and Tukey's test to compare 
the means. All analyses were performed at 5\% significance level, using the Stata graphs 16.1 software.

\section{RESULT}

The color values of the substrate before and after the procedures were A4 and A3,5, respectively. Three different treatment conditions were considered (Group 1, Group 2, and Group 3), with or without the influence of coffee pigmentation. Table 2 shows their descriptive statistics. After analyzing data normality with the Shapiro-Wilk and Levene tests to assess homoscedasticity, the data obtained were subjected to one-factor Analysis of Variance (ANOVA) and Tukey's test to compare the means, which did not show statistical difference among the groups at significance level of $\mathrm{p}<0.01$. Therefore, the color change experienced by the presence or absence of coffee did not influence the color change obtained with bleaching.

Table 2. Mean (standard deviation) of the color change $(\Delta \mathrm{E})$ data in the analysis of tooth enamel staining by coffee consumption during at-home tooth bleaching with $16 \%$ carbamide peroxide $(p<0.01)$

\begin{tabular}{cc}
\hline Groups & $\Delta \mathbf{E}$ \\
\hline Group 1 & $5.76 \pm(2.74)^{\mathrm{A}}$ \\
Group 2 & $8.83 \pm(5.11)^{\mathrm{A}}$ \\
Group 3 & $8.20 \pm(3.71)^{\mathrm{A}}$ \\
\hline
\end{tabular}

\section{DISCUSSION}

The present study used bovine teeth, because they are easier to obtain and standardize ${ }^{7}$. They are also commonly used in laboratory studies, because of their uniform composition and similarity to human teeth, both morphologically and histologically ${ }^{1}$.

The color difference caused by coffee ( $\mathrm{pH}$ 6.5) staining was assessed with an objective method using a spectrophotometer, which promoted more reliable and precise results ${ }^{2}$ than those obtained through the perception of color by the visual method, preventing personal factors that may interfere with the results 5 .

The specimens were stored in artificial saliva to simulate the remineralization in the oral cavity ${ }^{13}$, which may reverse the erosion process and porosity caused by bleaching agents that present neutral $\mathrm{pH}$ and oxidative capacity $(\mathrm{pH} 7.0)^{14}$. Several authors ${ }^{5,11,15}$ showed that storage in artificial saliva after tooth enamel bleaching helps repairing the loss of micro hardness established during tooth bleaching and the consequent susceptibility of enamel discoloration due to the retention of stains in such irregularities.

The results of the present study did not show statistical difference in color change between groups 2 and 3, which shows that the longer storage time in saliva in group 3 after tooth bleaching (four hours) was not significant for the lower pigmentation of specimens due to the remineralizing action of saliva during the time proposed. No previous staining was performed, as natural teeth generally do not have this characteristic and the development of the present in vitro research is to guarantee clinical application. In addition, previous staining could interfere with color evaluation, not identifying coffee immersion or staining as the cause.

The CIELab color system coordinates ( $\left.\mathrm{L}^{*}, \mathrm{a}^{*}, \mathrm{~b}^{*}\right)$ locate the object in a 3D color space and quantify the differences in lightness and chromaticity $\left(\Delta \mathrm{L}^{*}, \Delta \mathrm{a}^{*}, \Delta \mathrm{b}^{*}\right)$, for the total color difference $(\Delta \mathrm{E})$ calculation. The null hypothesis tested was confirmed, as the results obtained in $\Delta \mathrm{E}$ did not present any statistically significant difference, indicating that coffee intake did not interfere in the color change at the end of tooth whitening, either immediately or 4 hours after the end of the procedure. These findings contribute to the hypothesis that clinically the patient does not notice 
the color difference after tooth whitening with coffee consumption, considering $\Delta \mathrm{E}$ values were higher than 3.7 for all groups. Besides that, this study revealed that in $\Delta \mathrm{E}$ comparisons there was no significant influence between the groups tested, in agreement with previous studies findings ${ }^{11,16}$.

The bleaching process occurs possibly through the oxidation of organic compounds in dentin, while enamel only allows the passage of ions and small molecules ${ }^{5}$. An important aspect that corroborates the results of the present study is that enamel only allows the passage of molecules with low molecular weight through its structure, and the pigment presented in substances such as coffee present high molecular weight, so they cannot penetrate through tooth enamel ${ }^{11}$.

The consumption of colored foods and beverages may cause extrinsic pigmentation over time ${ }^{6}$; hence, their consumption is often restricted by dental professionals during tooth bleaching to ensure the longevity of the aesthetic result obtained ${ }^{17}$. Such propositions are supported by some authors who observed that consuming beverages such as red wine, coffee, and soft drinks cause color changes during tooth bleaching.

Attia et al. ${ }^{16}$ concluded that the contact with coloring agents should be avoided during tooth bleaching, because although treatment stability is not compromised during the process itself, consuming coffee after tooth bleaching has compromised its efficacy. At the same time, Berger et al. ${ }^{18}$ concluded that susceptibility to staining increased when the enamel was in contact with red wine after tooth bleaching.

Liporoni et al. ${ }^{19}$ investigated the susceptibility of bleached enamel to coffee and red wine staining at different times after tooth bleaching, and verified that wine interfered more than coffee with the tooth bleaching result. Côrtes et al. $^{3}$ assessed the influence of coffee and red wine staining on tooth color during and after tooth bleaching by analyzing color change with a spectrophotometer during tooth bleaching (three times a week) and after seven, 15, and 30 days. After tooth bleaching, both staining solutions caused enamel color changes, but wine resulted in greater staining than coffee ${ }^{19}$.

The process of tooth darkening occurs due to the formation of chemically stable structures responsible for the progressive installation of stains. The pigments are composed of great amounts of carbon molecules, which are broken and converted into intermediate compounds of lighter color. This chemical reaction changes the type, number, and relative position of atoms composing these molecules. During tooth bleaching, the carbon chains are transformed into $\mathrm{CO}_{2}$ and $\mathrm{H}_{2} \mathrm{O}$, which are gradually released along with the nascent oxygen. The saturation point is the moment in which most tooth bleaching occurs. After this stage, the pigments are no longer bleached and the bleaching agent starts to work in other compounds with carbon chains, such as the proteins of the enamel matrix.

The results of this study agree with other studies that verified no pigment action during tooth bleaching1,10,12,20. The contact of the bleached tooth enamel with coffee did not affect the bleaching of specimens, thus the recommendation for a white diet so that enamel is less susceptible to pigmentation becomes unnecessary.

Bleaching teeth with carbamide peroxide does not increase the susceptibility of enamel to staining. Such results are similar to the findings by Matis et al. ${ }^{13}$ and Farawati et al. ${ }^{12}$, whose experiments did not show negative influence of colored beverages on the final color of teeth. The present study also corroborates the findings of Monteiro et al.21, who assessed enamel color change after wine consumption immediately and one hour after bleaching, and did not observe color changes.

The coloration of foods is caused by the presence of chromogenic polyphenols. These compounds bond to proteins, as well as pellicles or bacteria in teeth. Any protein or reaction that occurred on the surface with the chromogenic polyphenols was saturated with the initial stain and became no longer available. The exacerbated in vitro effect due to tooth brushing and the 
movements of tongue and cheeks is a limitation of the study, because of its role in cleaning tooth surfaces, and it is considered a modifying factor ${ }^{1}$.

\section{CONCLUSION}

Coffee consumption did not affect the color change at the end of the bleaching, as well as 4 hours after the procedure, since there was no statistically significant difference between the groups.

\section{REFERENCES}

1. Carey CM. Tooth whitening: what we now know. J Evid Based Dent Pract. 2014 Jun;14 Suppl:70-6. http://dx.doi.org/10.1016/j.jebdp.2014.02.006. PMid: 24929591.

2. De Geus JL, De Lara MB, Hanzen TA, Fernández E, Loguercio AD, Kossatz S, et al. One-year follow-up of at-home bleaching in smokers before and after dental prophylaxis. J Dent. 2015 Nov;43(11):1346-51. http://dx.doi.org/10.1016/j.jdent.2015.08.009. PMid:26303401.

3. Côrtes G, Pini NP, Lima DA, Liporoni PC, Munin E, Ambrosano GM, et al. Influence of coffee and red wine on tooth color during and after bleaching. Acta Odontol Scand. 2013 Nov;71(6):1475-80. http://dx.doi.org/10.3109/00016357.2013.771404. PMid:23421870.

4. Karadas M, Tahan E, Demirbuga S, Seven N. Influence of tea and cola on tooth color after two in-office bleaching applications. J Res Dent. 2014;2(2):83-7. http://dx.doi.org/10.4103/2321-4619.136643.

5. Lee RJ, Bayne A, Tiangco M, Garen G, Chow AK. Prevention of tea-induced extrinsic tooth stain. Int J Dent Hyg. 2014 Nov;12(4):267-72. http://dx.doi.org/10.1111/idh.12096. PMid:25040739.

6. Pirolo R, Mondelli RFL, Correr GM, Gonzaga CC, Furuse AY. Effect of coffee and a cola-based soft drink on the color stability of bleached bovine incisors considering the time elapsed after bleaching. J Appl Oral Sci. 2014 Nov-Dec;22(6):534-40. http://dx.doi.org/10.1590/1678-775720130578. PMid:25075672.

7. Arévalo Pineda M, Larrucea Verdugo C. Recidiva del color dentario por té, café y vino: in vitro. Rev Clín Periodoncia Implantol Rehabil Oral. 2012 Ago;5(2):57-65.

8. Bazzi JZ, Bindo MJ, Rached RN, Mazur RF, Vieira S, Souza EM. The effect of at-home bleaching and toothbrushing on removal of coffee and cigarette smoke stains and color stability of enamel. J Am Dent Assoc. 2012 May;143(5):e1-7. http://dx.doi.org/10.14219/jada.archive.2012.0188. PMid:22547725.

9. Devigus A. The perfect smile. Int J Esthet Dent. 2014;9(4):465. PMid:25289381.

10. Melo CFM, Manfroi FB, Spohr AM. Microhardness and roughness of enamel bleached with $10 \%$ carbamide peroxide and brushed with different toothpastes: an in situ study. J Int Oral Health. 2014 Jul;6(4):18-24. PMid:25214727.

11. Rezende M, Loguercio AD, Reis A, Kossatz S. Clinical effects of exposure to coffee during at-home vital bleaching. Oper Dent. 2013 Nov-Dec;38(6):E229-36. http://dx.doi.org/10.2341/12-188-C. PMid:23570297.

12. Farawati FAL, Hsu S-M, O'Neill E, Neal D, Clark A, Esquivel-Upshaw J. Effect of carbamide peroxide bleaching on enamel characteristics and susceptibility to further discoloration. J Prosthet Dent. 2019 Feb;121(2):340-6. http://dx.doi.org/10.1016/j.prosdent.2018.03.006. PMid:30139674.

13. Matis BA, Wang G, Matis JI, Cook NB, Eckert GJ. White diet: is it necessary during tooth whitening? Oper Dent. 2015 May-Jun;40(3):235-40. http://dx.doi.org/10.2341/14-019-LIT. PMid:25748208. 
14. Zeczkowski M, Tenuta LMA, Ambrosano GMB, Aguiar FHB, Lima DANL. Effect of different storage conditions on the physical properties of bleached enamel: an in vitro vs. in situ study. J Dent. 2015 Sep;43(9):1154-61. http://dx.doi.org/10.1016/j.jdent.2015.06.004. PMid:26111927.

15. D'Arce MBF, Lima DAL, Aguiar FHB, Bertoldo CES, Ambrosano GMB, Lovadino JR. Effectiveness of dental bleaching in depth after using different bleaching agents. J Clin Exp Dent. 2013 Apr;5(2):e100-7. http://dx.doi.org/10.4317/jced.51063. PMid:24455056.

16. Attia ML, Aguiar FHB, Mathias P, Ambrosano GMB, Fontes CM, Liporoni PCS. The effect of coffee solution on tooth color during home bleaching applications. Am J Dent. 2009 Jun;22(3):175-9. PMid:19650600.

17. Lunardi N, Correr AB, Rastelli ANS, Lima DANL, Consani RLX. Spectrophotometric evaluation of dental bleaching under orthodontic bracket in enamel and dentin. J Clin Exp Dent. 2014 Oct; 6(4):e321-6. http://dx.doi.org/10.4317/jced.51168. PMid: 25593650.

18. Berger SB, Coelho AS, Oliveira VAP, Cavalli V, Giannini M. Enamel susceptibility to red wine staining after 35\% hydrogen peroxide bleaching. J Appl Oral Sci. 2008 May-Jun;16(3):201-4. http://dx.doi.org/10.1590/S1678-77572008000300007. PMid:19089218.

19. Liporoni PCS, Souto CMC, Pazinatto RB, Cesar ICR, de Rego MA, Mathias P, et al. Enamel susceptibility to coffee and red wine staining at different intervals elapsed from bleaching: a photoreflectance spectrophotometry analysis. Photomed Laser Surg. 2010 0ct;28(Suppl 2):S105-9. http://dx.doi.org/10.1089/pho.2009.2627. PMid:20863240.

20. Mori AA, Lima FF, Benetti AR, Terada RSS, Fujimaki M, Pascotto RC. Susceptibility to coffee staining during enamel remineralization following the in-office bleaching technique: an in situ assessment. J Esthet Restor Dent. 2016 Mar;28(Suppl 1):S23-31. http://dx.doi.org/10.1111/jerd.12134. PMid:25640880.

21. Monteiro D, Moreira A, Cornacchia T, Magalhães C. Evaluation of the effect of different enamel surface treatments and waiting times on the staining prevention after bleaching. J Clin Exp Dent. 2017 May;9(5):e677-81. http://dx.doi.org/10.4317/jced.53712. PMid: 28512546.

\section{CONFLICTS OF INTERESTS}

The authors declare no conflicts of interest.

\section{${ }^{*}$ CORRESPONDING AUTHOR}

João Victor Frazão Câmara, USP - Universidade de São Paulo, Faculdade de Odontologia de Bauru, Departamento de Ciências Biológicas, Alameda Doutor Octávio Pinheiro Brisolla, 9-75, Vila Cidade Universitária, 17012-901 Bauru - SP, Brasil, e-mail: jvfrazao92@hotmail.com 